\title{
Multiple rDNA ITS-types within the diatom Pseudo-nitzschia delicatissima (Bacillariophyceae) and their relative abundances across a spring bloom in the Gulf of Naples
}

\author{
Luisa Orsini, Gabriele Procaccini, Diana Sarno, Marina Montresor*
}

Stazione Zoologica ‘A. Dohrn', Villa Comunale, 80121 Naples, Italy

\begin{abstract}
The genus Pseudo-nitzschia includes a number of species responsible for blooms in coastal and open waters worldwide. P. delicatissima, a species reported as a potential source of amnesic shellfish poisoning (ASP), reaches high concentrations in the Gulf of Naples (Mediterranean Sea), where it regularly blooms in spring and, at times, in autumn. We assessed both intra- and interindividual genetic diversity of this species before and during a bloom (February to April 2001) by sequencing the internal transcribed spacer regions (ITS1 and ITS2) and the 5.8S gene of the nuclear ribosomal DNA. PCR products obtained from 70 strains were cloned and several ITS copies were sequenced for each strain to assess intra-individual polymorphism. Phylogenies showed the presence of 5 distinct, well-supported lineages within what was considered to be a single morphospecies. Genetic diversity was higher in pre-bloom conditions, while all strains collected at the height of the bloom clustered within a single major clade. Ultrastructural investigations carried out on selected strains revealed morphological features slightly different from the ones typical for P. delicatissima only in 1 strain, outside the major clade. Our results, supported by the analysis of the hypervariable domains of LSU (large subunit) rDNA carried out on selected strains, suggest the presence of cryptic diversity within $P$. delicatissima. Such diversity could in fact explain the existence of toxic and nontoxic strains within the same species and the occasional mismatches between 'species-specific' molecular probes and target species.
\end{abstract}

KEY WORDS: Diatoms $\cdot$ Pseudo-nitzschia delicatissima $\cdot$ ITS nDNA $\cdot$ Cryptic diversity $\cdot$ Bloom

Resale or republication not permitted without written consent of the publisher

\section{INTRODUCTION}

Large population size and high biogeographic dispersal of planktonic taxa should account for low levels of genetic differentiation, based on the assumption that the borderless marine environment should favor homogenization and prevent genetic isolation through rapid gene flow. This concept has been challenged in recent years. Molecular approaches demonstrated that genetic diversity can be important and highly structured in marine species (Palumbi 1994, Knowlton 2000, Norris 2000), including phytoplanktonic organisms belonging to distinct phylogenetic lineages (Medlin et al. 1996, Lewis et al. 1997, Bolch et al. 1999, LaJeunesse 2001, Montresor et al. 2003). Gene flow within large populations of pelagic species with high dispersal potential can be non-homogeneous, and genetic structuring is evident over the biogeographic distribution range, matching oceanic provinces, water masses and/or possible dispersal routes (Scholin et al. 1995, Bucklin et al. 1998, 2000). In other cases, high intraspecific diversity occurs without an apparent geographic partitioning (Medlin et al. 1996). Intraspecific genetic variability has been recorded also at narrow spatial scales, demonstrating that distinct genotypes sharing very similar morphological features can coexist in the 
same environment and suggesting the existence of cryptic taxa (Skov et al. 1997, Bolch et al. 1999, Montresor et al. 2003). Nonetheless, examples of taxa with very low intraspecific genetic diversity have also been reported (e.g. Connell 2000). All these different aspects of genetic variability have considerable implications for a sound estimate of global marine biodiversity, for the understanding of speciation mechanisms and for explaining differences in the ecological success of planktonic organisms.

Species of the genus Pseudo-nitzschia are abundant components of phytoplankton communities in both neritic and open-ocean environments over a wide latitudinal range from polar to temperate and equatorial waters (Iriarte \& Fryxell 1995, Horner et al. 2000, Hasle 2002, Smetacek et al. 2002). In the last few decades, this genus has attracted considerable scientific interest, since some species produce domoic acid, a neurotoxin responsible for amnesic shellfish poisoning (Mos 2001, www.bi.ku.dk/ioe/default.asp). The genus presently includes 27 species of needle-shaped, raphid pennate diatoms, which form chains of variable length by the overlapping of their ends (Hasle \& Syvertsen 1997, Lundholm \& Moestrup 2002, Lundholm et al. 2002b, 2003, Priisholm et al. 2002). Species identification within Pseudo-nitzschia can be rather complex; fine ultrastructural details of the frustule (e.g. numbers of striae and fibulae, poroid arrangement) need to be assessed by electron microscopy to key-out species. To facilitate recognition and enumeration of species in natural samples, species-specific molecular probes based on the sequences of the LSU (large subunit) nuclear ribosomal DNA have been designed (Miller \& Scholin 1996, 1998, Scholin et al. 1996). However, these molecular probes have shown at times a poor match when tested on natural samples (Parsons et al. 1999, Orsini et al. 2002).

The results of a long-term plankton program carried out at a coastal station in the Bay of Naples (Tyrrhenian Sea, Mediterranean Sea) showed that several Pseudonitzschia species occur in the area, with recurrent seasonal distribution patterns (Zingone et al. 2002, Ribera d'Alcalà et al. 2003). Among them, P. delicatissima regularly blooms in spring, and at times in autumn, reaching high cell concentrations. In the present study we followed the genetic diversity of $P$. delicatissima during the onset and peak of a spring bloom in the Bay of Naples. Our aim was to test the existence of 1 or multiple populations and to assess the level of genetic diversity within the bloom. Several molecular markers are now available for testing genetic diversity at distinct hierarchical levels (Feral 2002). We used the internal transcribed spacer regions (ITS1 and ITS2) and the 5.8S gene, which have been widely utilized for phylogenetic inferences at and below the species level
(Coleman et al. 1994, van Oppen et al. 1995, Connell 2000, Kooistra 2002, LaJeunesse 2002, Lange et al. 2002). ITS regions are present in strings repeated hundreds of times in the genome, and variations within single genomes homogenize through concerted evolution in sexually interbreeding populations (Dover 1982).

\section{MATERIALS AND METHODS}

Sampling, cultures and morphological observations. Phytoplankton samples were collected at the coastal station MareChiara (MC) located 2 nautical miles (n miles) offshore in the Gulf of Naples (Tyrrhenian Sea, Mediterranean Sea) and at station 'Dina', located in open oligotrophic waters $18 \mathrm{n}$ miles offshore (surface samples at both stations). St MC was sampled weekly within a long-term sampling program (Ribera d'Alcalà et al. 2003), while Stn Dina was sampled at more irregular intervals from January to July 2001. Water samples for the quantitative estimation of phytoplankton cell concentration were collected with a Niskin bottle and preserved with formaldehyde $(0.8 \%$ final concentration). Cells were identified and counted under an inverted light microscope (LM) at a magnification of 400x. To obtain material for cell isolation, net phytoplankton samples were collected in the prebloom phase, during the peak phase and toward the end of a bloom in February to April 2001 and at the beginning of the spring bloom in March 2002 only at Stn MC (Table 1). The net was gently towed through the surface layer of the water column (about 1 to $2 \mathrm{~m}$ ), and the sample was stored at about $15^{\circ} \mathrm{C}$ in the dark until return to the laboratory. Small amounts (ca. 0.5 to $1 \mathrm{ml}$ ) of the sample were placed in single wells of a tissue culture plate and diluted with filtered seawater. Under the LM, Pseudo-nitzschia delicatissima specimens were recognized based on gross cell morphology. In particular, size and shape of the cells, cell overlapping and the aspect of the valve ends in girdle view were the characters considered to distinguish $P$. delicatissima from the other Pseudo-nitzschia species recorded in the Gulf of Naples. Single short chains of $P$. delicatissima were isolated with a micropipette under an inverted light microscope, washed in sterile seawater and placed in wells of a tissue culture plate containing $2 \mathrm{ml}$ of diluted (1:20) F/2 growth medium (Guillard 1983). The culture plates were incubated at a temperature of $18^{\circ} \mathrm{C}$, with a photon fluence rate of $100 \mu \mathrm{mol}$ photons $\mathrm{m}^{-2} \mathrm{~s}^{-1}$ (provided by cool-white fluorescent tubes) in a 12:12 h light:dark photo cycle for 3 to $4 \mathrm{~d}$, to allow the growth of several chains. All strains were then inspected using a Zeiss Axiovert inverted microscope to re-isolate chains for molecular analyses. 
Table 1. Pseudo-nitzschia delicatissima. Sampling dates, sampling stations, number of strains and GenBank accession numbers for ITS (internal transcribed spacer region) and LSU (large subunit; marked with an asterisk) sequences obtained in this study. MC: coastal station; Dina: offshore station; n: no. of strains

\begin{tabular}{|c|c|c|}
\hline Sampling dates (station) & $\mathrm{n}$ & Strain code (GenBank accession nos.) \\
\hline 13 Feb 2001 (MC) & 9 & $\begin{array}{l}\text { 4-01 (AY519276); 5-01 (AY519287); 6-01 (AY519288); 10-01 (AY519273); } \\
\text { 11-01 (AY519289); 12-01 (AY519277); 15-01 (AY519278); 17-01 (AY519290); } \\
\text { 18-01 (AY519291) }\end{array}$ \\
\hline 15 Mar 2001 (MC) & 7 & $\begin{array}{l}\text { 19-01 (AY519296); 20-01 (AY519297); 21-01 (AY519274); 24-01 (AY519298); } \\
\text { 28-01 (AY519292); 29-01 (AY519299); 30-01 (AY519300) }\end{array}$ \\
\hline 10 Apr 2001 (MC + Dina) & $18+12$ & $\begin{array}{l}\text { 32-01 (AY519301); 33-01 (AY519302); 34-01 (AY519303); 36-01 (AY519304); } \\
\text { 37-01 (AY519282); 38-01 (AY519338); 39-01 (AY519293); 40-01 (AY519305); } \\
\text { 42-01 (AY519306); 43-01 (AY519307); 44-01 (AY519308); 45-01 (AY519309); } \\
\text { 46-01 (AY519310); 49-01 (AY519339); 50-01 (AY519311); 52-01 (AY519312); } \\
\text { 53-01 (AY519313); 54-01 (AY519314); 55-01 (AY519294); 57-01 (AY519340); } \\
\text { 58-01 (AY519341); 59-01 (AY519342); 63-01 (AY519286); 64-01 (AY519316); } \\
\text { 65-01 (AY519285); 66-01 (AY519315); 68-01 (AY519284); 71-01 (AY519283); } \\
\text { 75-01 (AY519317); 80-01 (AY519343) }\end{array}$ \\
\hline 24 Apr 2001 (MC) & 23 & $\begin{array}{l}\text { 98-01 (AY519344); 99-01 (AY519345); 101-01 (AY519318); 103-01 (AY519319); } \\
\text { 112-01 (AY519320); 113-01 (AY519321); 114-01 (AY519322); 115-01 (AY519323); } \\
\text { 117-01 (AY519346); 118-01 (AY519324); 121-01 (AY519325); 122-01 (AY519326); } \\
\text { 123-01 (AY519327); 124-01 (AY519279); 125-01 (AY519328); 126-01 (AY519329); } \\
\text { 128-01 (AY519280); 129-01 (AY519347); 131-01 (AY519295); 133-01 (AY519330); } \\
\text { 136-01 (AY519331); 139-01 (AY519332); 140-01 (AY519333) }\end{array}$ \\
\hline 27 Mar 2001 (MC) & 6 & $\begin{array}{l}\text { 18-02 (AY519334) }(\mathrm{AY} 519349)^{*} ; \text { 20-02 (AY519275) (AY519348)* }{ }^{*} 21-02(\mathrm{AY} 519281) \\
(\mathrm{AY} 519350)^{*} ; 24-02(\mathrm{AY} 519335)(\mathrm{AY} 519351)^{*} ; 26-02(\mathrm{AY} 51933)(\mathrm{AY} 519352)^{*} ; \\
27-02(\mathrm{AY} 519336)(\mathrm{AY} 519353)^{*}\end{array}$ \\
\hline
\end{tabular}

We also included 6 Pseudo-nitzschia delicatissima strains collected at the beginning of the bloom in March 2002 in the molecular analyses and examined them with transmission electron microscopy (TEM). These strains were grown in $30 \mathrm{ml}$ of culture medium. Exponentially growing cells were fixed with formaldehyde (final concentration $0.8 \%$ ), cleaned with $10 \% \mathrm{HNO}_{3}$ and $40 \% \mathrm{H}_{2} \mathrm{SO}_{4}$, and washed with distilled water. A drop of the cleaned material was placed on a Formvarcoated grid and observed with a Philips TEM $400 \mathrm{mi}-$ croscope. Numerous natural samples collected at the sampling station $\mathrm{MC}$, as well as clonal cultures of the different Pseudo-nitzschia species recorded in the area, have been prepared over the years for LM and TEM investigations with the method illustrated above to test the ultrastructural characters that distinguish the different species and to provide a check for the routine identification with LM of species in natural samples.

ITS direct PCR amplification and sequencing. PCR amplification was performed directly on short chains of cells (see last subsection). Cells were transferred into PCR Eppendorf tubes using the smallest possible volume (1 to $2 \mu \mathrm{l}$ ) of culture medium to avoid salt contamination. Negative control tubes were prepared with $2 \mu \mathrm{l}$ of sterile filtered seawater. Preliminary trials were performed, isolating single cells of Pseudo-nitzschia delicatissima with a micropipette. DNA amplification was successful, but relatively poor, providing only a few nanograms of DNA.
The ITS region was amplified in PCR using the universal primers ITS1 and ITS4 (White et al. 1990). Cells were amplified in $20 \mu \mathrm{l}$ reaction mix containing $2.5 \mathrm{U}$ of Taq (Boehringer), $0.2 \mathrm{mmol}$ of each nucleotide and 20 pmol of each primer. We performed 35 cycles (1 min at $94^{\circ} \mathrm{C}$, $1 \mathrm{~min}$ at $51^{\circ} \mathrm{C}$ and 2 min at $72^{\circ} \mathrm{C}$ ), with an initial denaturing step of $10 \mathrm{~min}$ at $95^{\circ} \mathrm{C}$. Amplified DNA fragments were purified with the QUIAEX II purification kit (Qiagen). Purified PCR products were cloned in pCR IITOPO vector with the TOPO TA cloning kit according to the manufacturer's instructions (Invitrogen). Vector primers (M13 rev and T7) and 2 suitably designed internal primers (Deli-d forward; 5'-GATTCACGAGGTCTTGCAATTCG-3'; Deli-r reverse; 5'-CGAATTGCAAGACCTCGTGAA-TC-3') were used as sequencing primers. Sequences were obtained with a CEQ 2000 DNA Analysis System (Beckman), using a DyeTerminator cycle sequencing kit. To assess intra-strain variability, 1 to 5 cloned sequences for each strain were analysed. A total of 231 sequences of the whole ITS region were obtained.

ITS sequence analysis. Sequences were aligned using Clustal W (Thompson et al. 1994) in the Bioedit 4.5.8 computer package (Hall 1999). ITS regions recognition in the alignment was done according to Hershkovitz \& Lewis (1996). The number of different haplotypes was calculated with the DAMBE computer program (Xia 2000), and the number of polymorphic sites was calculated using MEGA 2.1 (Kumar et al. 
2001). Phylogenetic significance of informative sites was assessed by comparing the measure of skewedness (g1-value) obtained under the random trees option in PAUP $^{*}$ (phylogentic analysis using parsimony) with the empirical threshold values given in Hillis \& Huelsenbeck (1992). Phylogenetic analyses were performed with the total ITS1-5.8S-ITS2 rDNA region and with ITS1 and ITS2 separately for both the total number of cloned sequences and the consensus sequences calculated for each diatom strain. Phylogenetic relationships were inferred using distance analysis. Neighbor-joining (NJ) trees (Saitou \& Nei 1987) were obtained according to the Kimura 2-parameter model, with the neighbor-joining option in MEGA 2.1, and branches statistical support was obtained with 1000 bootstrap replicates (Kumar et al. 2001).

LSU sequence analysis. For the 6 Pseudo-nitzschia strains collected in March 2002, a fragment of LSU rDNA spanning the D1 and D3 hypervariable domains was also sequenced. Amplifications were performed following Orsini et al. (2002), and amplification products were directly sequenced using PCR primers as sequencing primers. Sequences were aligned with 3 LSU sequences of $P$. delicatissima (SZN-B18, SZN-B19, SZN-B33) obtained from the same geographic area, and a sequence of $P$. fraudulenta (SZN-B21) was used as outgroup. (For GenBank accession numbers see Orsini et al. 2002.) Phylogenetic relationships were inferred by the methods detailed above.

\section{RESULTS}

In 2001, Pseudo-nitzschia delicatissima started to be recorded in net samples in February. In the samples examined for quantitative analyses, the species was recorded from the beginning of April until mid-May, reaching its highest con-

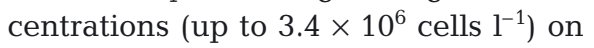
April 10 (Fig. 1). At the offshore station
'Dina', $P$. delicatissima was present at considerably lower densities (up to $0.4 \times 10^{6}$ cells $1^{-1}$ on April 3). In February to April 2001, the water column was still mixed and characterized by low temperature values $\left(15^{\circ} \mathrm{C}\right)$. Transient density stratifications occurred in the surface layer ( 5 to $10 \mathrm{~m}$ ) due to rain events that lowered salinity values (F. Corato unpubl. data). In spring 2002, the species was present in the same period, but peak concentrations were lower (up to $0.8 \times 10^{6}$ cells $1^{-1}$ on April 30).

\section{Genetic diversity}

The total length of the ITS1-5.8S-ITS2 regions of Pseudo-nitzschia delicatissima strains ranged from 758 to $867 \mathrm{bp}$. ITS1 and ITS2 ranged from 280 to 346 and from 318 to $379 \mathrm{bp}$, respectively, whereas the 5.8S region ranged from 155 to 163 (Table 2). Comparisons among sequences obtained from single individuals through cloning showed little differences, with Kimura 2 -parameter distance ranging from 0 to 0.024 . Phylogenetic analyses of the consensus sequences of all strains collected during the spring bloom showed a relatively high level of genetic diversity, with strains grouping into 5 different lineages (Fig. 2). Alignment

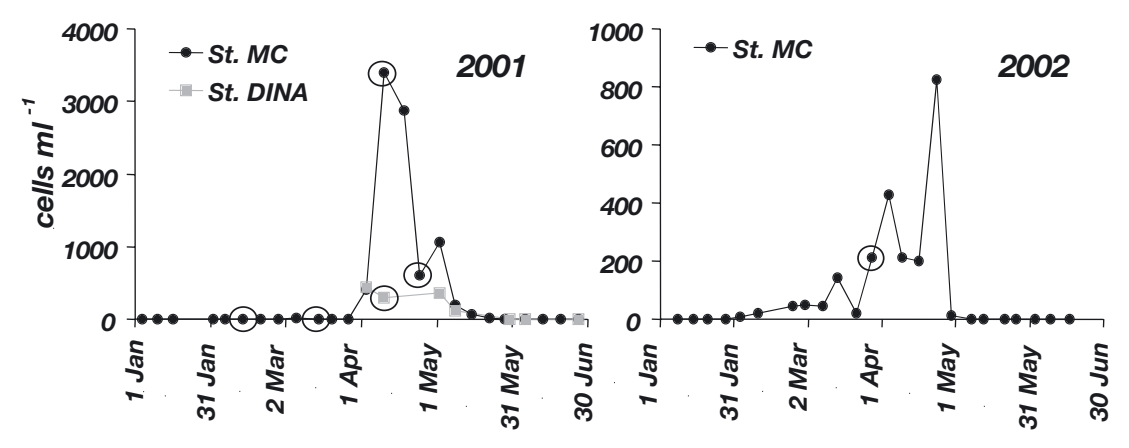

Fig. 1. Pseudo-nitzschia delicatissima. Cell concentration (cells $\mathrm{ml}^{-1}$ ) during spring blooms at coastal station MC and offshore station 'Dina'. Sampling dates for molecular analyses are encircled; note different scales for cell concentration between years

Table 2. Pseudo-nitzschia delicatissima. Polymorphism of ITS1, 5.8S and ITS2 regions for the 3 clades in Fig. 2. Polymorphism was calculated on total alignment. For Strains 10-01 and 21-01, which branch out at the base of the tree, only sequence length is reported. n: no. of sequences; L: Length; VS: variable sites; PIS: parsimony-informative sites

\begin{tabular}{|c|c|c|c|c|c|c|c|c|c|c|}
\hline \multirow{2}{*}{$\begin{array}{l}\text { Clade/Strain } \\
\text { no. }\end{array}$} & \multirow[t]{2}{*}{$\mathrm{n}$} & \multicolumn{3}{|c|}{ - ITS1 } & \multicolumn{3}{|c|}{$-5.8 \mathrm{~S}$} & \multicolumn{3}{|c|}{- ITS2 - } \\
\hline & & $\mathrm{L}$ & VS & PIS & L & VS & PIS & $\mathrm{L}$ & VS & PIS \\
\hline Clade 1 & 66 & $330-346$ & 24 & 1 & $155-163$ & 18 & 3 & $349-379$ & 34 & 0 \\
\hline Clade 2 & 3 & $280-281$ & 0 & 0 & $160-161$ & 0 & 0 & $318-326$ & 0 & 0 \\
\hline Clade 3 & 4 & $342-344$ & 1 & 0 & $155-161$ & 0 & 0 & $345-346$ & 0 & 0 \\
\hline $10-01$ & 1 & 344 & - & - & 159 & - & - & 364 & - & - \\
\hline 21-01 & 1 & 326 & - & - & 161 & - & - & 365 & - & - \\
\hline
\end{tabular}




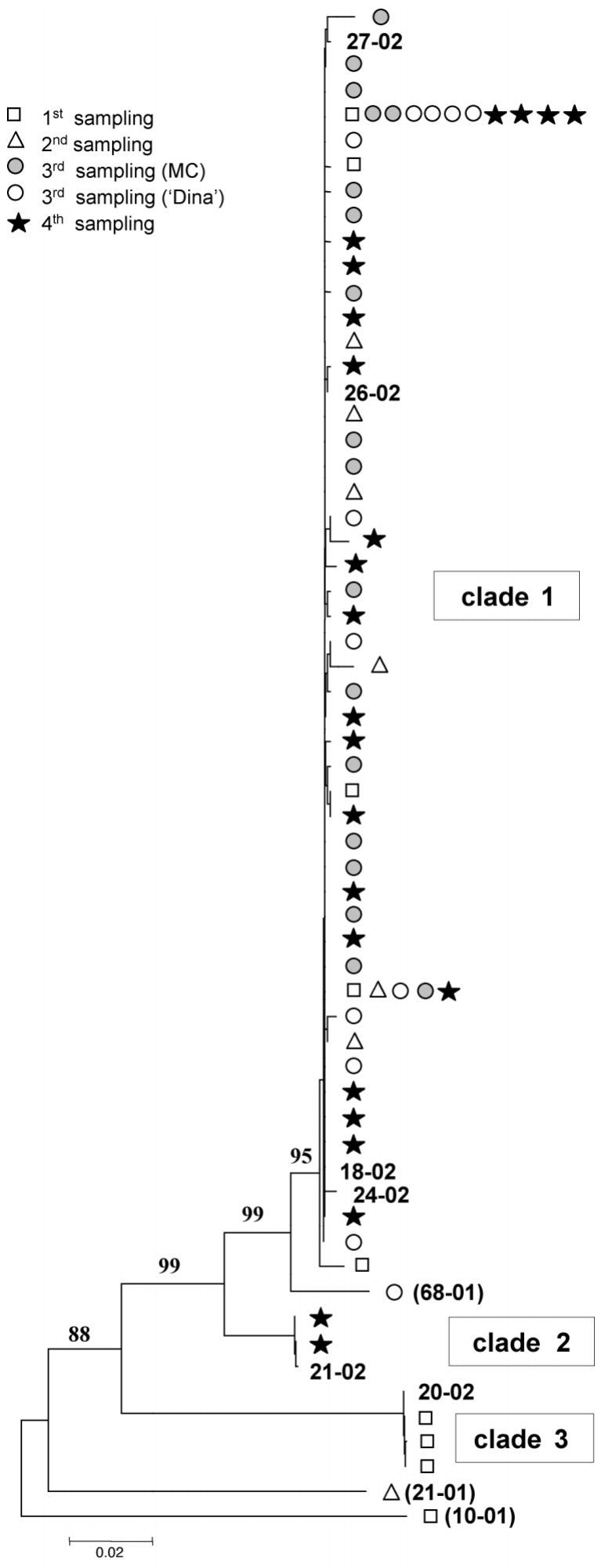

Fig. 2. Pseudo-nitzschia delicatissima. Neighbor-joining trees inferred for ITS rDNA using Kimura 2-parameter model. Bootstrap values (1000 replicates) $>50 \%$ are shown above branches. Strains collected on different sampling dates in 2001 are marked with different symbols. Strain code is given in parentheses next to symbol for those strains mentioned in text. The 6 strains collected in 2002 are indicated within clades was straightforward, though in a few cases it became problematic in the ITS1 and at the very end of the ITS2. The difficulties were not caused by troublesome reading, because all separate sequences within the same strain clearly showed the same aberrant pattern. Alignment among clades was almost impossible in a region of ITS1 between Positions 76 and 255, which was excluded from subsequent analyses because it showed alignment ambiguities and indels (insertion-deletion events). The final alignment comprised 988 positions. It also showed significant phylogenetic structure $(\mathrm{g} 1=-2.2858$ given 157 parsimony-informative sites and ca. 20 genetically distinctly different taxa) above the background noise (threshold g1 $=-0.2$ given 15 taxa and 100 sites). Variation was not evenly distributed and the large majority of sequences were highly similar in the first analysis of the alignment. Phylogenetic structure within this group of sequences ( $\mathrm{g} 1=-0.1721$ given 8 parsimonyinformative sites and ca. 30 distinct taxa, all positions included) was found to be insignificant (threshold g1 = -0.18 given 10 characters and 25 taxa).

High diversity was detected in the pre-bloom phase (first and second sampling dates) when strains grouped into 4 distinct, well-supported branches (Fig. 2). On the third sampling date, when the bloom reached its peak, all strains collected both at the coastal station $\mathrm{MC}$ and at the offshore station 'Dina' grouped together (Clade 1). Only 1 strain (68-01) fell at a basal position of Clade 1 . The large majority of strains isolated toward the end of the bloom (fourth sampling date) clustered again into Clade 1. However, 3 strains grouped in a new clade (Clade 2) located at the base of the major one. Of the 6 additional strains collected in the prebloom phase in March 2002, 4 fell into Clade 1, while 2 (Strains 20-02 and 21-02) clustered into the minor Clades 2 and 3, respectively (Fig. 2).

The 3 clades were characterized by a different number of sequences, thus preventing precise comparisons of genetic variability among them. In general, minor clades were highly homogeneous, while higher polymorphism was present in Clade 1, due also to the presence of a few more divergent sequences (Table 2). Excluding the most divergent strain (68-01), which was located in a basal position of Clade 1, the number of variable sites within Clade 1 droped from 76 to 56 . The sequence of Strain 68-01 was characterized by short indels in the ITS2 region, while it was completely alignable in the variable ITS1 region that was deleted from the final alignment. These regions were instead characteristic of each distinct clade, providing potential clade-specific signatures. Phylogenetic relationships among the Pseudo-nitzschia delicatissima strains were also evaluated considering all cloned ITS rDNA sequences for each strain. Multiple sequences (2 to 5) 
from the same strain did not always cluster together, although they always clustered within the same clade.

Results obtained with ITS sequences were confirmed by LSU sequence analysis. The 4 strains collected in the 2002 grouping into Clade 1 (Strains 18-02, 24-02, 26-02 and 27-02) were almost identical in their LSU sequences (no variable sites, excluding gaps). Sequences of Strains 20-02 and 21-02 were, instead, located independently outside the major clade (Fig. 3).

\section{Morphological analysis}

Ultrastructural investigations carried out on natural samples and culture material from the Gulf of Naples over the years confirmed the recurrent presence of specimens with gross and fine morphological features typical for Pseudo-nitzschia delicatissima as reported in the original description of the species by Hasle (1965) and in the following detailed investigations by Hasle \& Syvertsen (1997) and Skov et al. (1999). All $P$. delicatissima strains isolated in 2001 and 2002 show the same gross morphology under the LM, with spindle-shaped valves and truncated ends in girdle view (Fig. $4 \mathrm{a}, \mathrm{b}, \mathrm{c}$ ). TEM of the 6 strains isolated in 2002 revealed the presence of a central larger interspace and a number of striae and fibulae per $10 \mu \mathrm{m}$ ranging from 33 to 41 and from 20 to 28, respectively (Table 3). The strains grouping in the major clade and Strain 21-02 grouping into Clade 3 (Fig. 2) showed a valve ultrastructure typical for the species, with striae bearing 2 parallel rows of triangular to hexagonal small poroids with hymenate vela, in numbers of 9 to 11 per $\mu \mathrm{m}$ (Fig. 4d,e; Table 3). Cells of Strain 20-02 in Clade 3 (Fig. 4c), however, had a slightly wider transapical axis (Table 3) and showed a somewhat different organization and number of poroids on the valve face. Within a single valve, there were sections with striae having

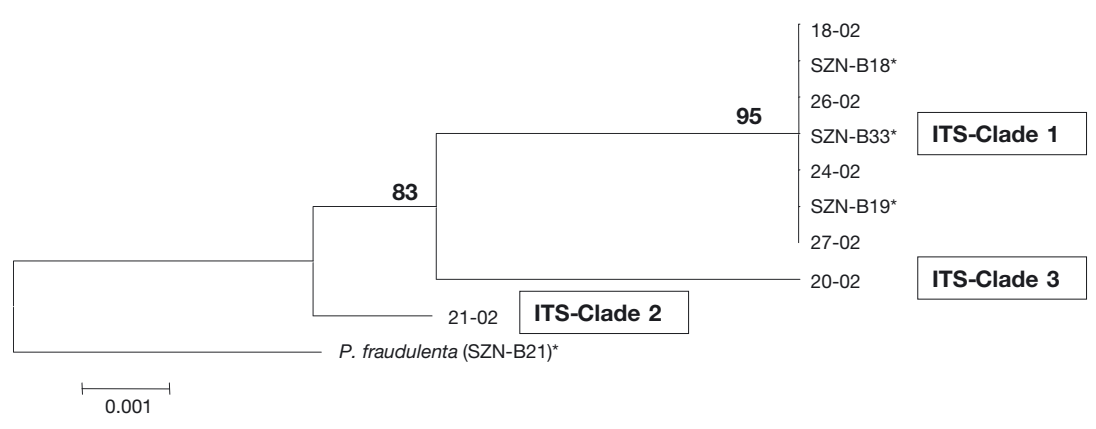

Fig. 3. Pseudo-nitzschia delicatissima. Neighbor-joining tree inferred for hypervariable domains D1-D3 of LSU rDNA of the 6 strains collected in 2002 and of additional strains analyzed by Orsini et al. $(2002)^{(*)}$. Bootstrap values (1000 replicates) $>50 \%$ are shown above branches. $P$. fraudulenta SZN-B27 was used as outgroup
2 rows of parallel, almost regularly spaced, poroids and other sections in which poroids were less regular and where 2 to 4 opposite poroids tended to join, forming a single circular and larger poroid (Fig. 4f,g). In addition, the number of poroids in Strain 20-02 ranged between 5 and $9 \mu^{-1}$ (Table 3); this is less than the number reported for $P$. delicatissima (Hasle 1965). The ultrastructure of the cingular bands did not reveal any significant difference among strains, showing variability within single strains that overlapped the range of variability among strains. In particular, the valvocopula was either 1 large poroid high (this poroid could also be split into 2 to 3 irregular sectors) or 2 small poroid high, and this variability was recorded in all strains except 20-02, in which valvocopula striae only 2 small poroids high were observed.

\section{DISCUSSION}

This study represents one of the few attempts to follow genetic diversity during the evolution of a diatom bloom. Molecular analyses performed on ITS rDNA sequences revealed an unexpectedly high level of genetic diversity within Pseudo-nitzschia delicatissima, which was previously considered a well-defined morphospecies. In the pre-bloom phase, when $P$. delicatissima was recorded only in the net samples and was thus present at very low concentration, strains clustered into 4 distinct lineages, showing that different ITS types co-occur in the water column. However, genetic diversity briskly decreased during the peak phase of the bloom, when all strains grouped into a single clade. Also, strains collected on the same date at a station located $18 \mathrm{n}$ miles offshore clustered within the same major clade, as did the majority of the strains collected 2 wk later, toward the end of the bloom. This indicates that over an extensive area and for its whole duration, the bloom was attributable to only 1 among the ITS types present in the Gulf of Naples.

Sampling coverage represents one of the major constraints when dealing with species whose abundance in the water column is in the order of $10^{5}$ to $10^{6}$ cells $\mathrm{l}^{-1}$. Hence, during the prebloom phase, genetic diversity was most certainly underestimated. In fact, if a random sampling of 16 strains sharing the same gross morphology at this stage already resulted in the detection of 4 distinct genetic lineages, a more intensive sampling effort could have detected even more lineages. The same is true for the lack of records, during 


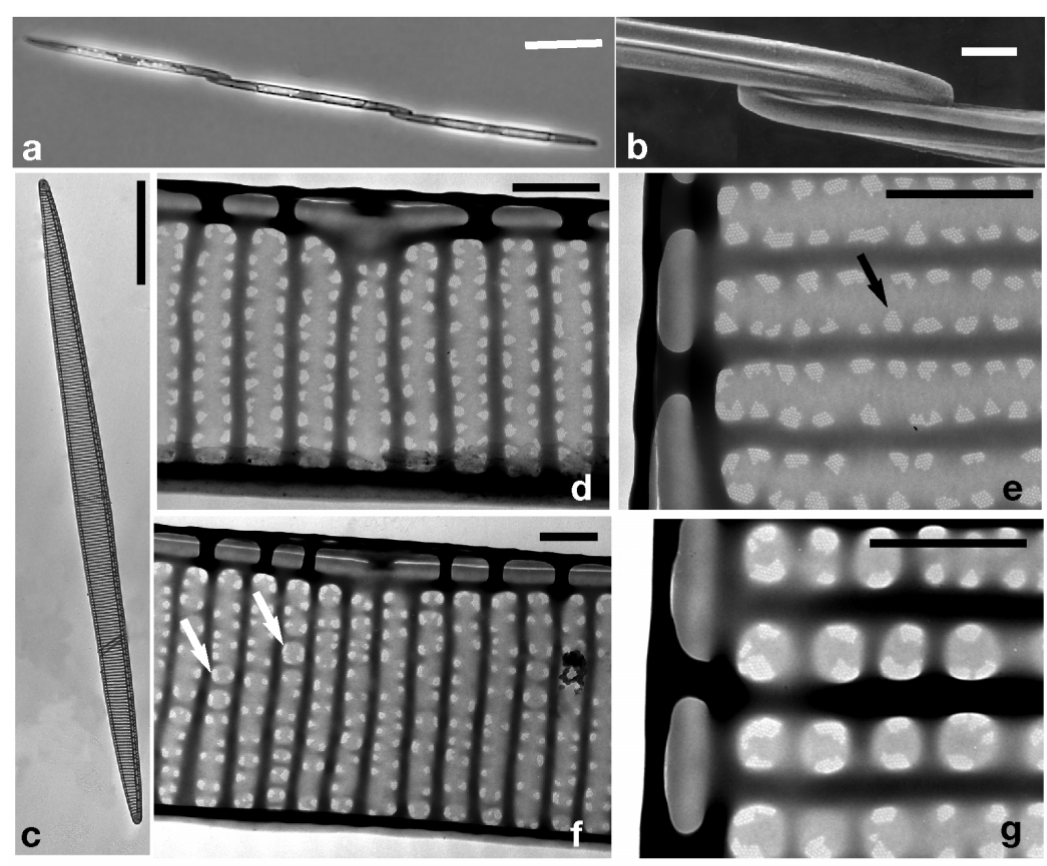

Fig. 4. Pseudo-nitzschia delicatissima. Light and electron micrographs. (a) Chain in girdle view (light microscope, LM); (b) part of colony in girdle view showing truncated apical ends (scanning electron microscope, SEM); (c) complete valve in valvar view (transmission electron microscope, TEM); (d) central part of valve of Strain 18-02 showing central larger interspace, note typical structure of the striae with 2 parallel rows of small poroids (TEM); (e) detail of stria showing small poroids with hymenate vela (arrowed) (TEM); (f) central part of valve of Strain 20-02 showing central larger interspace, note anomalous structure of the striae showing at some points (arrowed) clustering of small poroids to form larger poroids (TEM); (g) detail of a stria (Strain 20-02) showing poroids

$($ TEM). Scale bars $=($ a) $020 \mu \mathrm{m},(b)=1 \mu \mathrm{m},(\mathrm{c})=5 \mu \mathrm{m},(\mathrm{d}-\mathrm{g})=0.5 \mu \mathrm{m}$

sity. Second, these results could also explain the failure of 'species-specific' molecular probes that target only 1 among the various genotypes present in a morphospecies (Parsons et al. 1999, Scholin et al. 1999, Orsini et al. 2002).

\section{Genetic diversity}

The results of the phylogenetic analysis suggest that distinct reproductively isolated species exist within Pseudonitzschia delicatissima. All clades detected in the phylogenetic trees were in fact supported by significant bootstrap values. Moreover, the differences detected with ITS sequences were supported by the results obtained on a selected number of strains using the less variable D1 and D3 hypervariable domains of the LSU nDNA. Domains D1 and D3 have been used to assess interspecific phylogenies in the genus Pseudo-nitzschia (Lundholm et al. 2002a, Orsini et al. 2002). Moreover, multiple ITS sequences obtained for each single strain always clustered in the same clade, strongly supporting reproductive isolation and suggesting that introgression did not occur in recent times. Likewise, the low level of intra-strain polymorphism in $P$. delicatissima compared with polymorphism

the peak phase of the bloom, of representatives of the sister lineages recorded in the pre-bloom phase. This does not indicate their disappearance from the water column, but the small probability of them being detected at the peak of the bloom.

The finding of cryptic diversity for Pseudo-nitzschia delicatissima has notable implications. First, it shows that the use of light microscopy for identification of phytoplankton species underestimates species diver- recorded among multiple strains within a clade, suggests equilibrium between mutations and the homogenizing effects of concerted evolution (Hillis \& Davis 1988). Concerted evolution can only work when sexual reproduction occurs regularly, supporting the idea that the genetically similar but not identical strains representing the blooming population undergo sexual reproduction and recombination. The presence of recombinants between highly divergent ITS haplo-

Table 3. Pseudo-nitzschia delicatissima. Morphometric characters of selected strains belonging to different clades (illustrated in Fig. 2). TA: transapical axis (valve width)

\begin{tabular}{|c|c|c|c|c|c|}
\hline Strain (clade) & $\mathrm{TA}(\mu \mathrm{m})$ & Striae/10 $\mu \mathrm{m}$ & Fibulae/10 $\mu \mathrm{m}$ & Poroids/1 $\mu \mathrm{m}$ & Band striae/10 $\mu \mathrm{m}$ \\
\hline 18-02 (1) & $1.8-2$ & $33-35$ & 22 & $8-11$ & $45-46$ \\
\hline $24-02$ (1) & $1.75-2$ & $33-35$ & 22 & 9 & $44-48$ \\
\hline $26-02(1)$ & $<2$ & 36 & 24 & 9 & $45.5-47.5$ \\
\hline $27-02(1)$ & $1.8-2$ & $35-40$ & 23 & $9-10$ & $47-50$ \\
\hline $21-02(2)$ & $<2$ & $36-41$ & $24-28$ & $10-11$ & $42-53$ \\
\hline 20-02 (3) & $2.35-2.64$ & $36-38$ & $20-23$ & $5-9$ & $44-46$ \\
\hline
\end{tabular}


types (i.e. those belonging to different ITS clades), would in fact have resulted in considerable polymorphism among ITS types of the same strain, as recorded for the haptophyte Phaeocystis globosa (Lange et al. 2002) and for the brown seaweed Macrocystis pyrifera (Coyer et al. 2001). In the latter case, the high divergence was considered as indication for hybridization between genotypes from geographically distinct areas.

A direct comparison of divergence values among ITS sequences of congeneric species is only possible with the ITS1 region that was used to support distinction between Pseudo-nitzschia pungens and P. multiseries. In that case a divergence value of $27 \%$ was recorded (Manhart et al. 1995). Pairwise divergence values, calculated comparing the ITS1 consensus sequence of each of the 3 clades and the single sequences outside these clades (see Fig. 2), ranged from 10.2 to $30.9 \%$ over 236 valid common sites, thus offering further support for the existence of cryptic species within the analyzed strains.

Yet, we do not rule out hybridization events completely. In 1 case, crosses between isolates belonging to genetically different clades have resulted in extremely poorly growing hybrids, sharing ITS sequences from both parental lineages (A. Amato \& L. O. unpubl. data). Whether these crosses can lead to fertile progeny and the extent to which such events can occur in the field remains to be elucidated. The strains from which Consensus Sequences 71-01 and 68-01 were collected could represent typical examples of offsprings of such hybrids, because their sequences have the characteristics of recombinants. The midsections of these sequences align well with the other sequences included in Clade 1, but their $3^{\prime}$ end or 5' ends vary considerably. Hybridization has been reported as a possible speciation mechanism (Schluter 2001) and, if demonstrated to occur among Pseudo-nitzschia species, could account for the high genetic diversity recorded within this genus. The analysis of a larger set of sequences reflecting the whole diversity of the $P$. delicatissima species complex and mating experiments among isolates representing different ITS types are currently being carried out (A. Amato, M. Montresor) to test the extent of reproductive isolation among genetically distinct strains.

\section{Morphological diversity}

Ecological studies typically use light microscopy for analysis of phytoplankton samples, but identification of Pseudo-nitzschia species with this tool is not easy and often not possible. In addition to P. delicatissima, 5 other Pseudo-nitzschia species ( $P$. galaxiae, P. pseudodelicatissima, $P$. multistriata, $P$. fraudulenta, $P$. sub- fraudulenta, in order of abundance) are commonly found in the Gulf of Naples (Zingone et al. 2002). Using LM, $P$. delicatissima was differentiated from the other congeneric species by its relatively narrow (ca. $2 \mu \mathrm{m}$ ) transapical length, the cut-off apical ends of the cell in girdle view and the relatively limited cell overlapping (1/7 to $1 / 10$ of the cell length) when forming chains. The examination of ultrastructural features of the silica frustule using TEM is however required for a correct species classification within the genus Pseudonitzschia. The presence/absence of a larger interspace in the middle of the raphe, the organization pattern of poroids on the valve surface, the number of striae and fibulae, the shape and the density of poroids, and the ornamentation of the girdle bands are the major ultrastructural features on which the taxonomy of this genus is based (Hasle \& Syvertsen 1997). TEM investigations of numerous natural samples carried out over the years at our laboratory showed an apparent lack of ultrastructural variability, which gave us the confidence to properly identify the species in LM. This assumption induced us to by-pass culture establishment, and DNA was amplified performing PCR on a few monoclonal cells. Direct cell amplification has been in fact used for a number of phytoplankton organisms (Barker et al. 2000, Bolch 2001), and the method presents advantages in avoiding DNA extraction and overcoming the problem of somatic/sexual mutations potentially accumulating in cultures (Murphy 1978). However, the finding of putative cryptic species within what was considered to be a single morphospecies during the 2001 bloom led us to isolate other strains the following year in order to support our results with ultrastructural analyses with TEM. Unfortunately, we succeeded in isolating representatives of only 3 of the 5 ITS lineages; 6 strains belonging to Clades 1 and 2 (Fig. 2) shared the same shape and arrangement of poroids into 2 parallel rows, a number of fibulae and striae in the range reported in the literature (Hasle \& Syvertsen 1997, Skov et al. 1999, Priisholm et al. 2002). Strain 20-02, belonging to Clade 3 , showed apparently minor morphological differences that matched those reported for the still to be described species $P$. dolorosa sp. ined. (N. Lundholm pers. comm.). These differences, i.e. an irregular arrangement of the poroids in some sections of the valve, their lower density per $1 \mu \mathrm{m}$ and the slightly wider transapical axis of the cells (see Table 3) are impossible to appreciate by LM, and have been interpreted as intraspecific variability when examining TEM micrographs collected over the years in the Gulf of Naples. Our results in fact show that 2 out of the 3 ITS lineages cannot be distinguished, even after ultrastructural studies using TEM, while the third lineage including Strain 20-02 apparently presents some distinctive 
ultrastructural characters. The examination of ultrastructural features of a higher number of strains is however necessary to appreciate the whole range of morphological diversity and plasticity within P. delicatissima, especially as concerns quantitative morphological characters. Moreover, molecular phylogenies are required to identify phylogenetically sound morphological traits to be used for the identification of the distinct genotypes. We cannot claim to have completely covered the diversity spectrum of $P$. delicatissima-like species in our study area, but it is remarkable that the sampling of about 70 strains over a relatively short time interval allowed the finding of 5 distinct ITS types within what was identified as a single morphospecies.

\section{Ecological implications}

Cryptic or pseudo-cryptic species have been reported for several marine organisms belonging to different phylogenetic lineages and living in a wide variety of habitats (Knowlton 1993). The finding of cryptic species in the same environment leads to the hypothesis that different biological niches should exist to account for their coexistence. One possible explanation is that they thrive under different environmental scenarios. Distinct combinations of environmental factors such as irradiance conditions, day length, water temperature or turbulence can alternatively select for one of the genotypes over the annual cycle or even over longer pluriannual periods. In the Gulf of Naples, Pseudo-nitzschia delicatissima often shows a second peak of abundance in autumn, when water temperature is higher than in spring and the water column is still stratified (Zingone et al. 2002, Ribera d'Alcalà et al. 2003). It remains to be tested whether this late bloom is attributable to the same ITS type as that recorded in spring, to one of the more rare lineages, or even to a different one not sampled during the present investigation. In a pioneer study carried out on Skeletonema costatum analyzing isozyme banding patterns, genetically distinct populations were shown to dominate spring and autumn blooms, but diversity was considerable among strains isolated in the 2 seasons (Gallagher 1980). Genetic distance among the different populations was comparable to that existing among different species of plants, and differences in photosynthetic performances were detected in spite of an apparent morphological identity (Gallagher et al. 1984, Gallagher \& Alberte 1985). A similar pattern of genetic diversity was detected for $S$. costatum over 2 consecutive years, and the succession of the different genotypes was hypothesized to be under cyclic natural selection exerted by environmental factors (Gallagher
1980). Isozyme analysis showed high levels of genetic diversity also among strains of the pennate diatom $P$. pseudodelicatissima isolated from coastal waters of Denmark and Sweden (Skov et al. 1997). No relationship was apparent between the banding patterns and the geographic origin of the strains, and diversity was also high among isolates collected during the same bloom.

The simultaneous presence of distinct cryptic species in the same area could be also attributable to biological factors such as differences in life cycle strategies, or the control exerted by predators or parasites. Different timings in sexual reproduction, in the capability of producing resting stages and their germination could set distinct time windows for the presence of selected genotypes in the water column. Selective infection by distinct fungi and protozoans has been reported for different sympatric demes of freshwater diatoms (Canter \& Jaworski 1982, 1983, Mann 1999). Different cryptic species could also differ in their capacity for producing toxic defense compounds. Indeed, both toxic and nontoxic strains have been reported for species producing both paralytic shellfish poisoning (PSP) and ASP toxins (e.g. Bates et al. 1998, Higman et al. 2001), and strainspecific differences in the production of aldehydes has been also recorded (Pohnert et al. 2002). A few isolates of Pseudo-nitzschia delicatissima from the Gulf of Naples tested for domoic acid production were found to be non-toxic (Orsini et al. 2002). However, toxic strains of this species have been reported from Canada and New Zealand (Moestrup et al. 2002). What has been previously interpreted as intraspecific diversity in the production of chemical compounds could be explained in the light of cryptic diversity and represent a possible selective advantage of a certain genotype.

\section{Perception of diversity}

The finding of cryptic species within Pseudonitzschia delicatissima has obvious implications for our perception of the diversity of phytoplankton organisms. Classification systems for diatoms and other microscopic organisms are largely based upon their morphological features (Mann 1999). As our resolution capability increases or as more detailed morphological investigations are undertaken, the number of species increases. Molecular approaches now provide new tools for testing the morphological species concept and allow for the detection of phylogenetically meaningful characters for species circumscription. As an example, molecular analyses revealed 3 cryptic species within the globally distributed foraminiferan Orbulina universa, and their distinction was supported by minor morphological features cou- 
pled with distinct ecological preferences (de Vargas et al. 1999). The finding of cryptic diversity among several marine planktonic taxa highlights the fact that a notable fraction of the biodiversity has been overlooked by classical morpho-taxonomy. However, this can be also seen as a sign of our deep ignorance about the biological traits of the organisms with which we are dealing (Knowlton 1993, 2000). As for diatoms, we mainly base our phylogenies and taxonomic frameworks on morphological features of the silica frustule surrounding diatom cell, but we still have a very little understanding of the adaptive and evolutionary significance of these minute characters. Moreover, estimates of phenotypic plasticity, and a sounder knowledge of mating behavior, and reproductive isolation mechanisms will undoubtedly allow better circumscription of phytoplankton species and unveil the diversity hidden behind similar morphologies (Mann et al. 1999, Mann 2002).

Acknowledgements. We wish to thank W. H. C. F. Kooistra for helpful comments and suggestions, N. Lundholm for sharing unpublished data and comments, the Molecular Biology Service of the Stazione Zoologica for technical support during sequencing, and G. Forlani for TEM preparations. This work is part of the $\mathrm{PhD}$ thesis in Algal Biology (University of Messina, Italy/Stazione Zoologica 'A. Dohrn', Italy) of L.O.

\section{LITERATURE CITED}

Barker GL, Konopka A, Handley BA, Hayes PK (2000) Genetic variation in Aphanizomenon (Cyanobasteria) colonies from the Baltic Sea and north America. J Phycol 36:947-950

Bates BB, Garrison DL, Horner RA (1998) Bloom dynamics and physiology of domoic-acid-producing Pseudo-nitzschia species. In: Anderson DM, Cembella AD, Hallegraeff GM (eds) Physiological ecology of harmful algal blooms. Springer-Verlag, Berlin, p 267-292

Bolch CJS (2001) PCR protocols for genetic identification of dinoflagellates directly from single cyst and plankton cells. Phycologia 40:162-167

Bolch CJS, Blackburn SI, Hallegraeff GM, Vaillancourt RE (1999) Genetic variation among strains of the toxic dinoflagellate Gymnodinium catenatum (Dinophyceae). J Phycol 35:356-367

Bucklin A, Caudill CC, Guarnieri M (1998) Population genetics and phylogeny of planktonic copepods. In: Cooksey KE (ed) Molcular approaches to the study of the ocean. Chapman \& Hall, London, p 303-318

Bucklin A, Kaartvedt S, Guarnieri M, Goswami U (2000) Population genetics of drifting (Calanus spp.) and resident (Acartia clausi) plankton in Norwegian fjords. J Plankton Res 22:1237-1251

Canter HM, Jaworski GHM (1982) Some observations on the alga Fragilaria crotonensis Kitton and its parasitism by two chytridiaceous fungi. Ann Bot (Lond) 49:429-446

Canter HM, Jaworski GHM (1983) A further study on parasitism of the diatom Fragilaria crotonensis Kitton by chytridiaceous fungi in culture. Ann Bot (Lond) 52:549-563

Coleman AW, Suarez A, Goff LJ (1994) Molecular delineation of species and syngenes in volvocalean green algae
(Chlorophyta). J Phycol 30:80-90

Connell LB (2000) Nuclear ITS region of the alga Heterosigma akashiwo (Chromophyta; Raphydophyceae) is identical in isolates from Atlantic and Pacific basins. Mar Biol 136:953-960

Coyer JA, Smith GJ, Andersen RA (2001) Evolution of Macrocystis spp. (Phaeophyceae) as determined by ITS1 and ITS2 sequences. J Phycol 37:574-585

de Vargas C, Norris R, Zaninetti L, Gibbs SP, Pawlowski J (1999) Molecular evidence of cryptic speciation in planktonic foraminifera and their relation to oceanic provinces. Proc Natl Acad Sci USA 96:2864-2868

Dover G (1982) Molecular drive: a cohesive mode of species evolution. Nature 299:111-117

Feral JP (2002) How useful are the genetic markers in attempts to understand and manage marine biodiversity? J Exp Mar Biol Ecol 268:121-145

Gallagher JC (1980) Population genetics of Skeletonema costatum (Bacillariophyceae) in Narragansett Bay. J Phycol 16:464-474

Gallagher JC, Alberte RS (1985) Photosynthetic and cellular photoadaptive characteristics of three ecotypes of the marine diatom, Skeletonema costatum (Grev.) Cleve. J Exp Mar Biol Ecol 94:233-250

Gallagher JC, Wood AM, Alberte RS (1984) Ecotypic differentiation in the marine diatom Skeletonema costatum: influence of light intensity on the photosynthetic apparatus. Mar Biol 82:121-134

Guillard RRL (1983) Culture of phytoplankton for feeding marine invertebrates. In: Berg CJJ (eds) Culture of marine invertebrates: selected readings. Hutchinson Ross Publishing, Stroudsberg, PA, p 108-132

Hall TA (1999) BioEdit: a user-friendly biological sequence alignment editor and analysis program for Windows 95/98/NT. Nucleic Acids Symp Ser 41:95-98

Hasle GR (1965) Nitzschia and Fragilariopsis species studied in the light and electron microscopes. II. The group Pseudonitzschia. Skr Nor Vidensk-Akad Oslo I. Mat-Naturvidensk Kl 18:1-45

Hasle GR (2002) Are most of the domoic acid-producing species of the diatom genus Pseudo-nitzschia cosmopolites? Harmful Algae 1:137-146

Hasle GR, Syvertsen EE (1997) Marine diatoms. In: Tomas CR (ed) Identifying marine phytoplankton. Academic Press, San Diego, p 5-385

Hershkovitz MA, Lewis LA (1996) Deep-level diagnostic value of the rDNA-ITS coding region. Mol Biol Evol 13: 1276-1295

Higman WA, Stone DM, Lewis JM (2001) Sequence comparison of toxic and non-toxic Alexandrium tamarense (Dinophyceae) isolates from UK waters. Phycologia 40:256-262

Hillis DM, Davis SK (1988) Ribosomal DNA: intraspecific polymorphism, concerted evolution, and phylogeny reconstruction. Syst Zool 37:63-66

Hillis DM, Huelsenbeck (1992) Signal, noise, and reliability in molecular phylogenetic analyses. J Hered 83:189-195

Horner RA, Hickley BM, Postel JR (2000) Pseudo-nitzschia blooms and physical oceanography off Washington state, USA. S Afr J Mar Sci 22:299-308

Iriarte JL, Fryxell GA (1995) Micro-phytoplankton at the equatorial Pacific $\left(140^{\circ} \mathrm{W}\right)$ during the JGOFS EqPac time series studies: March to April and October 1992. Deep-Sea Res II 42:559-583

Knowlton N (1993) Sibling species in the sea. Annu Rev Ecol Syst 24:189-217

Knowlton N (2000) Molecular genetic analyses of species boundaries in the sea. Hydrobiologia 420:73-90 
Kooistra WHCF (2002) Molecular phylogenies of Udoteaceae (Bryopsidales, Chlorophyta) reveal nonmonophyly for Udotea, Penicillus, and Chlorodesmis. Phycologia 41: 453-462

Kumar S, Tamura K, Jakobsen IB, Nei M (2001) MEGA2: molecular evolutionary genetics analysis software. Arizona State University, Tempe

LaJeunesse TC (2001) Investigating the biodiversity, ecology, and phylogeny of endosymbiotic dinoflagellates in the genus Symbiodinium using the ITS region: in search of a 'species' level marker. J Phycol 37:866-880

LaJeunesse TC (2002) Diversity and community structure of symbiotic dinoflagellates from Caribbean coral reefs. Mar Biol 141:387-400

Lange M, Chen YQ, Medlin LK (2002) Molecular genetic delineation of Phaeocystis species (Prymnesiophyceae) using coding and non-coding regions of nuclear and plastid genomes. Eur J Phycol 37:77-92

Lewis RJ, Jensen SI, Denicola DM, Miller VI, Hoagland KD, Ernst SG (1997) Genetic variation in the diatom Fragilaria capucina (Fragilariaceae) along a latitudinal gradient across North America. Plant Syst Evol 204:99-108

Lundholm N, Moestrup $\varnothing$ (2002) The marine diatom Pseudonitzschia galaxiae sp. nov. (Bacillariophyceae), morphology and phylogenetic relationships. Phycologia 41:594605

Lundholm N, Daugbjerg N, Moestrup Ø (2002a) Phylogeny of the Bacillariaceae with emphasis on the genus Pseudonitzschia (Bacillariophyceae) based on partial LSU rDNA. Eur J Phycol 37:115-134

Lundholm N, Hasle GR, Fryxell GA, Hargraves PE (2002b) Morphology, phylogeny and taxonomy of species within the Pseudo-nitzschia americana-complex (Bacillariophyceae), with descriptions of the two new species $P$. brasiliana sp. nov. and $P$. linea sp. nov. Phycologia 41:480-497

Lundholm N, Moestrup Ø, Hasle GR, Hoef-Emden K (2003) A study of the Pseudo-nitzschia pseudodelicatissima/cuspidata complex (Bacillariophyceae): what is P. pseudodelicatissima? J Phycol 39:797-813

Manhart JR, Fryxell GA, Villac MC, Segura LY (1995) Pseudonitzschia pungens and $P$. multiseries (Bacillariophyceae): nuclear ribosomal DNAs and species differences. J Phycol 31:421-427

Mann DG (1999) The species concept in diatoms. Phycologia 38:437-495

Mann DG (2002) Diatom life cycles. In: Garcés E, Zingone A, Montresor M, Reguera B, Dale B (eds) LIFEHAB: life history of microalgal species causing harmful blooms. European Commission, Brussels, p 13-17

Mann DG, Chepurnov VA, Droop SJM (1999) Sexuality, incompatibility, size variation and preferential polyandry in natural populations and clones of Sellaphora pupula (Bacillariophyceae). J Phycol 35:152-170

Medlin LK, Barker GLA, Campbell L, Green JC, Hayes PK, Marie D, Wrieden S, Vaulot D (1996) Genetic characterisation of Emiliania huxleyi (Haptophyta). J Mar Syst 9:13-31

Miller PE, Scholin CA (1996) Identification of cultured Pseudonitzschia (Bacillariophyceae) using species-specific LSU rRNA-targeted fluorescent probes. J Phycol 32:646-655

Miller PE, Scholin CA (1998) Identification and enumeration of cultured and wild Pseudo-nitzschia (Bacillariophyceae) using species-specific LSU rRNA-targeted fluorescent probes and filtered-based whole cell hybridization. J Phycol 34:371-382

Montresor M, Sgrosso S, Procaccini G, Kooistra WHCF (2003) Intraspecific diversity in Scrippsiella trochoidea (Dinophyceae): evidence for cryptic species. Phycologia 42:56-70
Mos L (2001) Domoic acid: a fascinating marine toxin. Environ Toxicol Pharmacol 9:79-85

Murphy LS (1978) Biochemical taxonomy of marine phytoplankton by electrophoresis of enzymes. II. Loss of heterozygosity in clonal cultures of the centric diatoms Skeletonema costatum and Thalassiosira pseudonana. J Phycol 14:247-250

Norris RD (2000) Pelagic species diversity, biogeography, and evolution. Paleobiology 26(Suppl): 236-258

Orsini L, Sarno D, Procaccini G, Poletti R, Dahlmann J, Montresor M (2002) Toxic Pseudo-nitzschia multistriata (Bacillariophyceae) from the Gulf of Naples: morphology, toxin analysis and phylogenetic relationships with other Pseudonitzschia species. Eur J Phycol 37:247-257

Palumbi SR (1994) Genetic divergence, reproductive isolation, and marine speciation. Annu Rev Ecol Syst 25:547- 572

Parsons ML, Scholin CA, Miller PE, Doucette GJ, Powell CL, Fryxell GA, Dortch Q, Soniat TM (1999) Pseudo-nitzschia species (Bacillariophyceae) in Louisiana coastal waters: molecular probes field trials, genetic variability, and domoic acid analyses. J Phycol 35:1368-1378

Pohnert G, Lumineau O, Cueff A, Adolph S, Cordevant C, Lange M, Poulet SA (2002) Are volatile unsaturated aldehydes from diatoms the main line of chemical defence against copepods? Mar Ecol Prog Ser 245:33-45

Priisholm K, Moestrup Ø, Lundholm N (2002) Taxonomic notes on the marine diatom genus Pseudo-nitzschia in the Andaman Sea near the island of Phuket, Thailand, with a description of Pseudo-nitzschia micropora sp. nov. Diatom Res 17:153-175

Ribera d'Alcalà M, Conversano F, Corato F, Licandro P and 9 others (2003) Seasonal patterns in plankton communities in a pluriannual time series at a coastal Mediterranean site (Gulf of Naples): an attempt to discern recurrences and trends. Sci Mar 67(Suppl 3):65-83

Saitou N, Nei M (1987) The neighbor-joining method: a new method for reconstructing phylogenetic trees. Mol Biol Evol 4:406-425

Schluter D (2001) Ecology and the origin of species. Trends Ecol Evol 16:372-380

Scholin CA, Hallegraeff GM, Anderson DM (1995) Molecular evolution of the Alexandrium tamarense species complex (Dinophyceae): dispersal in the North American and West Pacific region. Phycologia 34:472-485

Scholin CA, Buck KR, Britschgi T, Cangelosi G, Chavez FP (1996) Identification of Pseudo-nitzschia australis (Bacillariophyceae) using rRNA-targeted probes in whole cells and sandwich hybridization formats. Phycologia 35:190-197

Scholin CA, Marin R, Doucette GJ, Powell CL, Haydock P, Howard J, Ray J (1999) DNA probes and a receptor-binding assay for detection of Pseudo-nitzschia (Bacillariophyceae) species and domoic acid activity in cultured and natural samples. J Phycol 35:1356-1367

Skov J, Lundholm N, Pocklington R, Rosendahl S, Moestrup $\varnothing$ (1997) Studies on the marine planktonic diatom Pseudonitzschia. 1. Isozyme variation among isolates of $P$. pseudodelicatissima during a bloom in Danish coastal waters. Phycologia 36:374-380

Skov J, Lundholm N, Moestrup Ø, Larsen J (1999) Potentially toxic phytoplankton. 4. Genus Pseudo-nitzschia (Diatomophyceae/Bacillariophyceae). In: Lindley JA (ed) ICES identification leaflets for plankton. ICES Leaflet No. 185. ICES, Copenhagen, p 2-23

Smetacek V, Klaas C, Menden-Deuer S, Rynearson TA (2002) Mesoscale distribution of dominant diatom species relative to the hydrographical field along the Antarctic polar front. Deep-Sea Res II 49:3835-3848 
Thompson JD, Higgins DG, Gibbson TJ (1994) Clustal W: improving the sensitivity of progressive multiple sequence alignment through sequence weighting, position-specific gap penalities and weight matrix choice. Nucleic Acids Res 22:4673-4680

van Oppen MJH, Draisma SGA, Olsen JL (1995) Multiple transArctic passage in the red alga Phycodrys rubens: evidence from nuclear rDNA ITS sequences. Mar Biol 123:179-188

White TJ, Bruns T, Lee S, Taylor J (1990) Amplification and direct sequencing of fungal ribosomal RNA genes for phylo-

Editorial responsibility: Otto Kinne (Editor),

Oldendorf/Luhe, Germany genetics. In: Innis MA, Gelfand DH, Sninsky JJ, White TJ (eds) PCR protocols. Academic Press, New York, p 315-322

Xia X (2000) Data analysis in molecular biology and evolution. Kluwer Academic, Boston

Zingone A, Licandro P, Nardella M, Sarno D (2002) Seasonality and interannual variation in the occurrence of species of the genus Pseudo-nitzschia in the Gulf of Naples (Mediterranean Sea). In: Abstract Book 10th International Conference on Harmful Algae, October 21-25 2002. St. Pete Beach, FL, p 315

Submitted: September 3, 2003; Accepted: January 27, 2004 Proofs received from author(s): April 5, 2004 